\title{
BERAGAM TUTURAN DALAM PEMBICARAAN SEHARI-HARI: SUATU TINJAUAN ETNOGRAFI KOMUNIKASI
}

\author{
E. Zaenal Arifin \\ Universitas Indraprasta PGRI \\ zaenalarifin_48@yahoo.com \\ zaenalarifin.28.wordpress
}

\begin{abstract}
ABSTRAK
Penelitian ini bersifat deskriptif-kualitatif. Tujuannya adalah ingin menginventarisasi berbagai tuturan dalam berkomunuikasi. Teori yang digunakan tergolong eklektik, yaitu gabungan teori etnografi komunikasi dan teori tuturan. Hasil penelian menyatakan bahwa dalam pembicaraan sehari-hari kita menggunakan berbagai tuturan, seperti pendapat pakar pragmatik Austin, yaitu verdiktif, eksersitif, komisif, behabitif, dan ekspositif.Adapun jika berdasarkan teori Searle, tuturan dalam pembicaraan kita adalah asertif, direktif; komisif,ekspresif, dan deklaratif.
\end{abstract}

Kata Kunci: tuturan, deskriptif-kualitatif, eklektik, verdiktif, eksersitif, komisif, behabitif, dan ekspositif.

\begin{abstract}
This research is qualitative-descriptive. The aim is to inventory various speeches in communication. The theory used is classified as eclectic, which is a combination of the ethnographic communication and speech act theory. The results of the study stated that in everyday conversation we used various utterances, such as Austin Pragmatic expert's opinion, namely verdictive, exersitive, commissive, behabitive, and expositive. As for it based on Searle theory, the speech in our conversation is assertive, directive, commisive, expressive, and declarative.
\end{abstract}

Key Word: speeches, qualitative descriptive, eclectic, verdictive, exersitive, commissive, behabitive, and expositive

\section{PENDAHULUAN}

\section{Latar Belakang}

Penelitian untuk pemetaan bahasa di Indonesia yang dikerjakan oleh Badan Pengembangan dan Pembinaan Bahasa, Kementerian Pendidikan dan Kebudayaan dilakukan 


\section{PUJANGGA}

sejak 1991 hingga 2017. Bahasa daerah di Indonesia yang telah diidentifikasi dan divalidasi sebanyak 733 bahasa dari 2.452 daerah pengamatan. Bahasa di wilayah Nusa Tenggara Timur, Maluku, Maluku Utara, Papua, dan Papua Barat belum semua teridentifikasi secara keseluruhan. (Sumber: http://www. repositori.perpustakaan. kemdikbud. go.id/id/eprint/4780/Diunduh 18/06/2018). Jika ditilik dari posisi jumlah bahasa di negaranegara seluruh dunia, Indonesia berada pada posisi kedua setelah Papua Nugini. Posisi pertama Papua Nugini dengan jumlah 867 bahasa, sedangkan Indonesia menempati posisi kedua dengan jumlah 733 bahasa (Sumber: http://www.brainly. co.id»/ Diunduh 17/06/2018).

Distribusi bahasa daerah di Indonesia rupanya berbanding terbalik antara jumlah bahasa dan jumlah penduduk. Pulau Jawa, misalnya, dengan jumlah penduduk 123 juta orang memiliki tidak lebih dari empat buah bahasa, yaitu bahasa Jawa, Sunda, Madura, dan Betawi. Sebaliknya, Papua Barat yang penduduknya hanya berjumlah 2 juta orang memiliki jumlah bahasa mencapai 271 buah. (Rosmanuddin, 2017 dalam http//:www. portalsatu.com/ read/ budaya/ 36621/Diunduh 17/06/2018).

Dari jumlah 733 bahasa itu, bahasa daerah yang penuturnya lebih dari satu juta orang sebanyak 10 bahasa, yakni (1) Bahasa Jawa, (2).. Bahasa Melayu-Indonesia, (3) Bahasa Sunda, (4) Bahasa Madura, (5) Bahasa Batak, (6) Bahasa Minangkabau, (7) Bahasa Bugis, (8) Bahasa Aceh, (9) Bahasa Bali, dan (10) Bahasa Banjar. (http://www.brainly.co.id`/Diunduh 17/06/2018).

Chambers (1980:74) menyatakan bahwa in many communities, different ethinic groups speak different langguage 'dalam berkomunikasi sehari-hari setiap etnik menggunakan bahasa daerah atau bahasa ibu yang berbeda-beda. Keberagaman bahasa daerah tersebut berdampak pada pemakaian bahasa Indonesia yang bervariasi pula. Misalnya, etnik Sunda berbeda dengan etnik Jawa, etnik Madura, dan etnik-etnik lain dalam berbahasa Indonesia. Pemakaian bahasa Indonesia setiap etnik juga memiliki variasi berdasarkan peristiwa tutur dan situasi tutur. Pemakaian bahasa Indonesia seperti di pasar jelas berbeda dengan pemakaian bahasa Indonesia di istana presiden atau di lembaga-lembaga pendidikan. Dengan kata lain, pemakaian bahasa cenderung berbeda bergantung pada siapa pembicara dan pendengar, di mana dituturkan, mengenai masalah apa, dalam suasana ramah atau suasana marah, dalam suasana santai atau suasana mencekam, dan seterusnya. (Sumber: http://www. usahid.ac.id/wp-content/ uploads/etnografi-komuni-kasi/ Diunduh 25/02/2018).

Etnografi adalah ilmu yang mempelajari deskripsi budaya suku-suku bangsa (etnik) yang hidup tersebar di muka bumi. Adapun etnografi komunikasi adalah bidang ilmu etnolinguistik tentang bahasa dalam hubungannya dengan semua variabel di luar bahasa, seperti kebudayaan etnisitas, dan faktor sosial lainnya. Faktor-faktor sosial itu mencakupi status sosial, tingkat pendidikan, umur, tingkat ekonomi, jenis kelamin, daerah tempat tinggal, dan sebagainya.

Komunikasi adalah suatu kegiatan pertukaran informasi antara penutur dan petutur (lawan tutur) melalui suatu bahasa atau tingkah laku. Dalam proses komunikasi terdapat tiga komponen, yaitu bahasa sebagai alat, baik aspek linguistik maupun aspek paralinguistik, informasi yang disampaikan, serta pihak partisipan sebagai pemberi informasi dan penerima 
informasi. Ketiga komponen komunikasi secara bersama-sama membentuk apa yang disebut dengan situasi tutur dan peristiwa tutur dalam suatu tindak tutur.

Tindak tutur adalah kemampuan seorang individu melakukan pembicaraan, yang mempunyai maksud tertentu sesuai dengan situasi tertentu. Dari jelasan tersebut dapat dilihat bahwa dalam tindak tutur, yang lebih ditekankan ialah arti tindakan dalam tuturannya. Hal ini sesuai dengan fungsi bahasa sebagai alat komunikasi, yang bertujuan merumuskan maksud dan melahirkan perasaan penutur. Selain itu, tindak tutur juga mencakup ekspresi psikologis, seperti berterima kasih dan memohon maaf, dan tindak sosial, seperti mengingatkan dan memerintahkan, atau membuat kontrak, seperti berjanji dan menamai.

Ketika kita berkomunikasi dengan orang lain, sejatinya kita melakukan tindakantindakan, seperti memberi laporan, membuat pernyataan-pernyataan, mengajukan pertanyaan, memberi peringatan, memberi janji, menyetujui, menyesali, dan meminta maaf. Pada sisi lain, ketika kita terlibat dalam percakapan, kita melakukan beberapa tindakan, seperti melaporkan, menyatakan, memperingatkan, menjanjikan, mengusulkan, menyarankan, mengkritik, meminta, dan lain-lain.

Berbagai tindak tutur yang terjadi dalam masyarakat, baik tindak tutur representatif, direktif, ekspresif, komisif, maupun deklaratif, baik tindak tutur langsung maupun tidak langsung, entah tindak tutur harafiah, entah tidak harafiah, entah kombinasi dari dua atau lebih tindak tutur tersebut, merupakan bahan sekaligus fenomena yang sangat menarik untuk dikaji secara pragmatis dan ilmiah.

\section{Rumusan Masalah}

Berdasarkan latar belakang di atas, rumusan masalah yang dikemukakan dalam penelitiam ini sebagai berikut.

1. Jenis-jenis tuturan apa saja yang digunakan seseorang dalam berbicara berdasarkan etnografi komunikasi?

2. Komponen-komponen apa saja yang memengaruhi suatu komunikasi?

3. Dalam setting apa saja seseorang dapat diajak berkomunikasi?.

\section{Tujuan Penelitian}

\section{Sesuai dengan rumusan masalah yang dikemukakan, tujuan penelitian ini adalah}

1. ingin menginventarisasi jenis-jenis tuturan yang digunakan seseorang dalam berbicara berdasarkan etnografi komunikasi;

2. ingin mengetahui komponen-komponen yang memengaruhi suatu komunikasi;

3. untuk mengetahui dalam setting apa saja seseorang dapat diajak berkomunikasi. 


\section{Metode dan Teknik}

Penelitian ini menggunakan meode deskripti kualitatif. Adapun teknik penelitian yang digunakan adalah teknik catat dan ralat semua hasil pembicaraan responden dan teknik studi pustaka.

\section{Kerangka Teori}

Teori yang dijadikan landasan penelitian ini adalah teori etnografi komunikasi dan pragmatik. Etnografi komunikasi adalah kajian tentang etnik (suku) yang dikaitkan dengan teori komunikasi yang terdiri atas variasi bahasa, tata cara bertutur, komunitas tutur, situasi tutur, peristiwa tutur, tindak tutur, komponen tutur, dan nilai-nilai di balik tutur. Dalam berkomunikasi seorang komunikator dan komunikannya menggunakan bahasa pada situasi tertentu. Bahasa dan situasi merupakan suatu kesatuan yang tidak dapat dipisahkan. Setiap tuturan selalu dikaitkan dengan situasi pembicaraan. Dalam kaitan itu, Hymes (1972:58 — 71) memerinci enam belas konteks pembicaraan, yang dipadatkan menjadi delapan unsur situasi bahasa, yakni 1) setting, 2) participant, 3) ends, 4) act, 5) key, 6) instrumental, 7) norms, dan 8) genre, yang diakronimkan dalam SPEAKING.

Penelitian ini juga menggunakan teori pragmatik. Pragmatik mempelajari makna satuan bahasa secara eksternal. Pragmatik merupakan suatu telaah umum mengenai bagaimana caranya konteks mempengaruhi peserta tutur dalam menafsirkan kalimat atau menelaah makna dalam kaitannya dengan situasi ujaran. Dengan memahami kaidah-kaidah pragmatik, baik bagi pembicara atau penutur maupun bagi pendengar atau mitra tutur diharapkan dapat menggunakan bahasa dalam percakapan sehari-hari. (Purwo, 1990)

\section{Tindak Tutur}

Teori tindak tutur ini diperkenalkan oleh Austin (1962), yaitu meskipun kalimat sering dipakai untuk memberitakan perihal keadaan, pengucapan kalimat-kalimat tertentu dalam keadaan tertentu, harus dianggap sebagai pelaksanaan suatu tindakan. Dalam hubungan itu, Austin membagi tidak tutur menjadi tindak lokusi, tindak ilokusi, dan tindak perlokusi. Teori ini diteruskan Searle, yang membagi tindak tutur ini ke dalam lima kategori, yaitu (1) representatif, (2) direktif, (3) komisif (4). ekspresif, dan (5) deklaratif.

1. Representatif adalah pernyataan tentang suatu keadaan .Dari segi pembicara apa yang dinyatakan itu mengandung kebenaran.

Contoh: (1) Katanya, Hasan punya dua istri, maka kalimat tadi dari segi pembicara menyatakan proposisi yang benar.

2. Tindak ujaran direktif: adalah ujaran yang dilakukan pembicara dengan tujuan agar pendengar melakukan sesuatu. Wujud tindak ujaran ini dapat berupa pertanyaan. Contoh: (2) Kapan kamu pergi ke Jakarta? Pertanyaan kalimat (2) dapat dituturkan a. berupa permintaan sangat lunak: (3) Mampir,ya ke Ciledug kalau ke Jakarta, 


\section{PUJANGGA}

atau (b) berupa sedikit menyuruh: (4) Ayo,dong, diminum jusnya.

3.Tindak ujaran komisif: Sama dengan tindak ujaran direktif, hanya arahnya berbeda .Pada ujaran direktif, si pendengarlah yang diharapkan melakukan sesuatu .Pada tindak ujaran komisif, perintah itu diarahkan kepada pembicara sendiri. Misalnya, (5) Biarlah, masalah tersebut akan saya selesaikan.

4. Tindak ujaran ekspresif: Dipakai oleh si pembicara bila ia menyatakan keadaan pisikologisnya mengenai sesuatu, misalnya menyatakan rasa terima kasih, belasungkawa, menyampaikan ucapan selamat, permintaan maaf dan juga mengumpat (mencaci). Contoh: (6) Kami sekeluarga turut berduka atas kepergian Ibunda Hj. Nursiah binti Abdul Azis.

5. Tindak ujaran deklaratif: menyatakan suatu keadaan baru yang muncul akibat ujaran yang lain. Misalnya, (7) Pemilihan Presiden akan dilakukan pada April 2019.

Dalam membahas pragmatik, Muhadjir (2015:235) memerinci teori Austin (1962) dan teori Searle (1975) tentang tindak tutur lebih lengkap dan lebih terperinci sebagai berikut. Austin (1992) membagi tindak tutur menjadi lima macam, yaitu verdiktif, eksersitif, komisif, behabitik, dan ekspositif (expositive).

a.verdictif (verdictive) tindak seperti melakukan .estimasi, menyatakan, memberikan, dan sebagainya;

b.eksersitif (exercitive) tindak seperti memerintah, menunjuk, dan memberi nasihat;

c.komisif (commissive) seperti melakukan promosi, menyatakan makud, atau bertaruh;

d.behabitif, seperti meminta maaf, memberi ucapan selamat, dan terima kasih;

e.ekspositif (expositive), seperti membantah, mendesak, dan memastikan.

Selanjutnya, tindak tutur menurut klasifikasi Searle (1975) terbagi menjadi lima macam, yaitu

a.asertif (assertive), misalnya menyatakan, mengusulkan membual, mengeluh,

mengemukakan pendapat, dan melaporkan;

b.direktiff (directive); misalnya memesan, memerintah, dan memohon;

c.komisif, seperti menjanjikan, menawarkan, berkaul;

d. ekspresif,. misalnya mengucapkan terima kasih, mengucapkan selamat, memberi maaf, memuji, mengucapkan belasungkawa;.

e.deklaratif, misalnya mengundurkan diri, membabtis, memecat, memberi nama, menjatuhkan hukuman, dan sebagainya. (Muhadjir, 2015:235)

Alwi et al. (2003) menyatakan bahwa konteks terdiri atas unsur-unsur, seperti situasi, pembicara, pendengar, waktu, tempat, adegan, topik, peristiwa, bentuk amanat, kode, dan sarana. Sementara itu, unsur konteks yang berupa sarana adalah wahana komunikasi yang dapat berwujud pembicaraan bersemuka atau melalui telepon, surat, telegraf, radio, dan televisi.

Menurut Hymes (1972): 21--22) di dalam peristiwa tutur ada sejumlah faktor yang menandai keberadaan peristiwa itu, yakni (a) setting atau scene, yaitu tempat dan suasana peristiwa tutur; (b) participant, yaitu penutur, mitra tutur, atau pihak lain; (c) end atau tujuan; (d) act, yaitu tindakan yang dilakukan penutur di dalam peristiwa tutur; (e) key, yaitu nada 
suara dan ragam bahasa yang digunakan di dalam mengekspresikan tuturan dan cara mengekspresikannya; (f) instrument, yaitu alat yang berupa bahasa tulis atau lisan, melalui telepon atau bersemuka; (g) norm atau norma, yaitu aturan permainan yang harus ditaati oleh setiap peserta tutur, dan (h) genre, yaitu jenis kegiatan, seperti wawancara, diskusi, kampanye, dan sebagainya. Konfigurasi fonem awal nama kedelapan faktor itu membentuk kata Speaking. Selanjutnya, ia mengemukakan bahwa ciri-ciri konteks itu mencakup delapan hal. Kedelapan ciri-ciri konteks yang relevan itu adalah penutur, mitra tutur, topik tuturan, waktu dan tempat bertutur, saluran atau media, kode (dialek atau gaya), amanat atau pesan, dan peristiwa atau kejadian.

\section{Konteks Sosial}

Bahasa membutuhkan konteks dalam pemakaiannya. Demikian pula sebaliknya, konteks baru memiliki makna jika di dalamnya terdapat tindak bahasa sehingga bahasa tidak hanya berfungsi dalam interaksi-interaksi yang diciptakan, tetapi bahasa juga membentuk dan menyediakan interaksi-interaksi yang sedang terjadi sebagai konteks.

\section{Situasi Tutur}

Rustono (1999:26) menyatakan bahwa situasi tutur adalah situasi yang melahirkan tuturan. Hal tersebut berkaitan dengan adanya pendapat yang menyatakan bahwa tuturan merupakan akibat, sedangkan situasi merupakan penyebab terjadinya tuturan.

Sebuah peristiwa tutur dapat terjadi karena adanya situasi yang mendorong terjadinya peristiwa tutur tersebut. Situasi tutur sangat penting dalam kajian pragmatik, karena dengan adanya situasi tutur, maksud dari sebuah tuturan dapat diidentifikasikan dan dipahami oleh mitra tuturnya. Sebuah tuturan dapat digunakan dengan tujuan untuk menyampaikan beberapa maksud atau sebaliknya. Hal tersebut dipengaruhi oleh situasi yang melingkupi tuturan tersebut. Keanekaragaman maksud mungkin disampaikan oleh penutur dalam sebuah peristiwa tutur dan mengungkapkan sejumlah aspek yang harus dipertimbangkan, seperti penutur dan lawan tutur, konteks, tujuan tuturan, tindak tutur sebagai bentuk aktivitas dan tuturan sebagai produk tindakan verbal (Leech, 1983).

Leech (1983) mengemukakan sejumlah aspek yang senantiasa harus dipertimbangkan dalam berkomunikasi. Aspek- aspek tersebut adalah sebagai berikut.

\section{Penutur dan Lawan Tutur}

Konsep penutur dan lawan tutur ini juga mencakup penulis dan pembaca apabila tuturan bersangkutan dikomunikasikan dengan media tulisan. Aspek-aspek yang berkaitan dengan penutur dan lawan tutur ini adalah usia, latar belakang, sosial ekonomi, jenis kelamin, tingkat keakraban, dan sebagainya.

\section{Tujuan Tuturan}

Tujuan tuturan adalah apa yang ingin dicapai penutur dengan melakukan tindakan bertutur. Semua tuturan memiliki tujuan, hal tersebut memiliki arti bahwa tidak ada tuturan 
yang tidak mengungkapkan suatu tujuan. .Bentuk-bentuk tuturan yang diutarakan oleh penutur selalu dilatarbelakangi oleh maksud dan tujuan tuturan.Dalam hubungan tersebut, bentuk tuturan yang bermacam-macam dapat digunakan untuk menyatakan satu maksud dan sebaliknya satu tuturan dapat menyatakan berbagai macam maksud.

\section{Tuturan sebagai Bentuk Aktivitas}

Yang dimaksud dari tuturan sebagai bentuk aktivitas adalah tindak tutur itu merupakan tindakan juga. Menuturkan sebuah tuturan dapat dilihat sebagai melakukan tindakan (act) (Austin, 1962, Gunarwan, 1994, dan Kaswanti Purwo, 1990).Di sini tuturan bukan merpakan entitas abstrak seperti tata bahasa, di sini tuturan adalah sebagai entitas yang kongkret jelas penutur dan lawan tuturnya, serta waktu dan tempat pengutaraanya.

Tuturan sebagai tindakan atau aktivitas memiliki maksud bahwa tindak tutur merupakan sebuah tindakan.Menuturkan sebuah tuturan dapat dilihat sebagai melakukan tindakan. Tuturan dapat dikatakan sebagai sebuah tindakan atau aktivitas karena dalam peristiwa tutur, tuturan dapat menimbulkan efek sebagaimana tindakan yang dilakukan oleh tangan atau bagian tubuh lain yang dapat menyakiti orang lain atau mengekspresikan tindakan.

Konteks: seorang ibu berkata kepada anaknya Ibu: (8) Wah, terasnya kotor sekali ya?. Anak : (segera mengambil sapu dan menyapu teras tersebut)

Berdasarkan peristiwa tutur tersebut tuturan yang dilakukan oleh Ibu merupakan tindakan menyuruh atau mendorong anak untuk membersihkan teras yang terlihat kotor. Tuturan tersebut menimbulkan efek pada mitra tutur yang mendengarkan tuturan tersebut seperti halnya didorong atau dipukul dengan menggunakan tangan. Dalam perilaku yang dilakukan oleh anak yang segera mengambil sapu dan menyapu teras merupakan efek dari ucapan Ibu tersebut.

\section{Tuturan sebagai Tindak Verbal}

Tindakan manusia dibedakan menjadi 2, yaitu tindakan verbal dan tindakan nonverbal. Memukul atau berjalan merupakan contoh dari tindakan nonverbal. Sementara berbicara merupakan tindakan verbal. Tindak verbal adalah tindak mengekspresikan kata-kata atau bahasa.

\section{Peristiwa Tutur}

Peristiwa tutur (speech event) adalah terjadinya atau berlangsungnya interaksi linguistik dalam satu bentuk ujaran atau lebih yang melibatkan dua pihak, yaitu penutur dan lawan tutur, dengan satu pokok tuturan, di dalam waktu, tempat, dan situasi tertentu (Chaer dan Agustina, 1995: 61). Perhatikan proses berlangsungnya tuturan (languageevent) berikut ini.Pembicara (O1) memiliki gagasan (yang belum diucapkannya), gagasan itu diwujudkannya ke dalam kode (encoding) yang berupa bahasa (kata, frasa, kalimat dsb.), kemudian kode itu diucapkannya (fonasi). Kode yang terucapkan itulah yang secara formal disampaikannya kepada orang yang diajaknya berbicara (O2). Kemudian, O2 membaca kode- 


\section{PUJANGGA}

kode itu (decoding) karena telah diucapkan atau dituliskan, menyimak (audisi), kemudian memahami kode. Lihat ringkasan berikut.

O1: punya gagasan $\rightarrow$ beri kode $\rightarrow$ ucapkan atau tuliskan

$\mathrm{O} 2$ : baca kode $\rightarrow$ simak kode $\rightarrow$ pahami kode

Adapun semua yang menjadi lingkungan terjadinya komunikasi disebut konteks.

Salah satu unsur yang menjadi lingkungan konteks dan dianggap penting ialah waktu dan tempat. Contoh berikut ini menunjukkan bahwa waktu dan tempat sangat berpengaruh terhadap makna wacana.

(9) "Masih pukul empat pagi. Jakarta sudah menggeliat bangun. Satu dua kendaraan sudah mulai melintas, tetapi kantor-kantor masih tertidur lelap. Taksi yang kami tumpangi ikut melintas di jalan yang masih sepi. Angin pagi yang sejuk dengan ramah menyapa kami ketika melewati Taman Monas yang rimbun. "Jika siang sedikit lagi, keadaan di taman ini akan jauh berbeda, Bu," kata supir taksi."

Wacana (9) itu menginformasikan keadaan Jakarta pada waktu pagi, Jakarta "menggeliat bangun", kendaraan mulai melintas. Suasana itu akan sangat berbeda jika siang datang. Sebaliknya, di kota lain barangkali pukul empat masih dianggap malam. Tafsiran itu biasanya didasarkan pada kondisi dan kebisasaan di tempat tertentu. Kota besar yang ramai dan seperti tidak pernah tidur, dan aktivitas kehidupan sudah dimulai sejak lewat tengah malam. Di jalan raya, pasar, dan terminal, misalnya, sudah ada orang yang bekerja.

Ada yang mengatakan bahwa konteks terjadinya percakapan dapat dibagi menjadi

a) konteks linguistik (linguisticcontext), berupa kalimatdalam percakapan;

b) konteks epistemik (epistemiccontext), yakni latar belakang pengetahuan yang diketahui bersama oleh partisipan;

c) konteks fisik (physicalcontext), meliputi tempat terjadinya percakapan, objek dalam percakapan, dan tindakan para partisipan;

d) konteks sosial (socialcontext), berupa relasi sosiokultural yang melengkapi hubungan di antara partisipan. (lihat Mulyana, 2005:24)

\section{Konsep-Konsep dalam Etnografi Komunikasi \\ Tata Cara Bertutur}

Tata cara bertutur (ways of speaking) mengandung gagasan dan peristiwa komunikasi di dalam suatu komunitas mengandung pola-pola kegiatan tutur sehingga kompetensi komunikatif seseorang mencakup pengetahuan tentang pola itu. Tata cara tersebut mengacu kepada hubungan antara peristiwa tutur, tindak tutur, dan gaya, di satu pihak, dengan kemampuan dan peran seseorang, konteks dan institusi, serta kepercayaan, nilai, dan sikap, di pihak lain.

Tata cara bertutur itu berbeda dari budaya yang satu ke budaya yang lain, bahkan yang paling mendasar sekalipun. Misalnya, di kalangan orang-orang kulit putih Amerika dari kelas menengah terdapat kaidah "tanpa kesenjangan, tanpa tumpang tindih" dalam giliran bertutur (turn-taking). Jika dua orang atau lebih terlibat dalam perpercakapan dan jika dua orang mulai berbicara dalam waktu yang sama (tanpa disengaja), dengan cepat yang satu memberi kesempatan kepada yang lain sehingga tidak terjadi tumpang tindih. 


\section{PUJANGGA}

Sebaliknya, jika terjadi kemacetan beberapa detik saja, para partisipan menjadi begitu merasa "tidak enak", kemudian seseorang akan mulai berbicara tentang hal-hal yang tidak penting sekadar untuk mengisi "kesenjangan".

Banyak definisi tentang komunitas tutur. Hymes berpendapat bahwa semua warga komunitas tutur saling terpaut bukan hanya oleh kaidah wicara yang sama, melainkan juga oleh setidak-tidaknya satu ragam (varietas) bahasa. Saville Troike menganggap persamaan bahasa itu tidak perlu, yang penting terdapat persamaan kaidah wicara..Troike juga menyebut adanya komunitas tutur yang tumpang tindih. Misalonya, seorang mahasiswa adalah warga kampus, tetapi juga warga asrama, warga suku, warga bangsa, dan seterusnya. Setiap komunitas mempunyai sedikit kaidah pembeda komunikasi, dan dalam hal-hal tertentu juga kaidah pembeda wicara. Ini berarti bahwa setiap penutur tidak perlu termasuk hanya ke dalam satu komunitas tutur atau ke dalam dua atau lebih komunitas tutur yang sama sekali berbeda. Orang biasanya menjadi anggota dari beberapa komunitas tutur pada saat yang sama. Orang akan mengubah perilaku tuturya, dengan menyesuaikan diri dengan komunitas yang melibatkan tutumya, dengan menambah mengurangi, dan mengganti kaidah perilaku komunikatif. Berikut ini dikemukakan beberapa pendapat tentang komunitas tutur.

Hudson (1980) berpendapat bahwa istilah komunitas tutur mengacu kepada "komunitas yang berdasarkan bahasa". Kajian tentang komunitas tutur ini banyak diminati oleh para linguis, setidak-tidaknya sejak Bloomfield menulis dalam buku Language (1933).

Batasan paling sederhana tentang komunitas tutur dikemukakan oleh Lyons (1970), Speech community is all the people who use a given language (or dialect)." (komunitas tutur adalah semua orang yang memakai suatu bahasa atau dialek tertentu). Menurut batasan ini, beberapa komunitas tutur dapat saja bertumpang tindih (jika ada para dwibahasawan) dan tidak perlu kesatuan sosial atau kesatuan kultural.

\section{Peristiwa dan Tindak Tutur}

Untuk mengkaji kebiasaan komunikasi di dalam suatu komunitas tutur, seorang peneliti harus mengamati unit-unit interaksi, yaitu situasi tutur (speech situation), peristiwa tutur (speech event), dan tindak tutur (speech act). Tindak tutur merupakan bagian dari peristiwa tutur, dan peristiwa tutur menjadi bagian dari situasi tutur. Situasi tutur adalah situasi yang dikaitkan dengan tuturan dan tidak ada kaitannya dengan linguistik, misalnya upacara, pertengkaran, dan percintaan. Peristiwa tutur berciri komunikatif dan terikat dengan aturan cara bertutur. Peristiwa tutur dapat terdiri atas satu atau lebih tindak tutur. Misalnya, gurauan yang terjadi dalam suatu percakapan (peristiwa tutur) dan terjadi di dalam suatu pesta (situasi tutur). Dimungkinkan pula suatu tindak tutur sekaligus mencakup peristiwa tutur dan situasi tutur, misalnya tindak tutur berdoa. Hymes berpendapat bahwa tindak tutur dipengaruhi oleh konteks sosial, bentuk gramatikal, dan intonasi.

Ada dua jenis tuturan, menurut Austin, yaitu ujaran konstatif dan performatif.

1. Tuturan konstantif ujaran yang tidak melakukan tindakan dan dapat diketahui salah-benarnya. Menurut Austin (1962), tuturan konstantif adalah jenis tuturan yang melukiskan suatu keadaan faktual, yang isinya boleh jadi merujuk ke suatu fakta atau 
kejadian historis yang benar-benar terjadi pada masa lalu. Tuturan konstantif memiliki konsekuensi untuk ditentukan benar atau salah berdasarkan hubungan faktual antara si penutur dan fakta sesungguhnya. Jadi, dimensi pada tuturan konstatif adalah benarsalah.Contoh: (10) Kamu terlihat bahagia.

2. Ujaran performatif, yaitu ucapan yang berimplikasi dengan tindakan si penutur sekalipun sulit diketahui salah-benarnya, tidak dapat ditentukan benar-salahnya berdasarkan faktanya karena ujaran ini lebih berhubungan dengan perilaku atau perbuatan si penutur. Ujaran seperti (11) Кати dipecat! atau (12) Dengan ini Saudara saya nyatakan bersalah merupakan contoh ujaran performatif.

\section{PEMBAHASAN}

\section{Tindak Tutur}

Tindak tutur merupakan aksi (tindakan) dengan menggunakan bahasa (Djajasudarma, 1994: 63). Bahasa digunakan pada hampir semua aktivitas. Kita menggunakan bahasa untuk menyatakan informasi (permohonan informasi, memerintah, mengajukan, permohonan, mengingatkan, bertaruh, menasihati, dan sebagainya). Kemudian, tindak tutur (istilah kridalaksana penuturan atau speech act, speech event) adalah pengajaran kalimat untuk menyatakan agar suatu maksud dari pembicara diketahui oleh pendengar (Kridalaksana, 1984: 154). Chaer (1995:65), menyatakan bahwa tindak tutur merupakan gejala individu, bersifat psikolinguistik dan keberlangsungannya ditentukan oleh kemampuan bahasa si penutur dalam mengahdapi situasi tertentu.

Searle di dalam bukunya Speech Acts: An Essay in The Philosophy of Language (dalam Wijana,1996:17), mengemukakan bahwa secara pragmatis setidak-tidaknya ada tiga jenis tindakan yang dapat diwujudkan oleh seorang penutur, yaitu tindak lokusi (locutionary act), tindak ilokusi (illocutionary act), dan tindak perlokusi (perlocutionary act).

Tindak tutur merupakan aksi (tindakan) dengan menggunakan bahasa (Djajasudarma, 1994:63). Bahasa digunakan pada hampir semua aktivitas. Kita menggunakan bahasa untuk menyatakan informasi (permohonan informasi, memerintah, mengajukan, permohonan, mengingatkan, bertaruh, menasehati, dan sebagainya). Kemudian tindak tutur (istilah Kridalaksana penuturan atau speech act, speech event) adalah pengajaran kalimat untuk menyatakan agar suatu maksud dari pembicara diketahui oleh pendengar (Kridalaksana, 1984:154). Richard (1995) mengemukakan bahwa tindak tutur (dalam arti yang sempit sekarang) adalah istilah minimal dari pemakaian situasi tutur/peristiwa tutur/tindak tutur.

Berkenaan dengan tindak tutur ini Chaer dan Leonie Agustine (1995) berpendapat bahwa tindak tutur merupakan gejala individual, bersifat psikologis, dan keberlangsungannya ditentukan oleh kemampuan bahasa si penutur dalam menghadapi situasi tertentu. Dalam tindak tutur itu yang lebih dilihat adalah makna atau arti tindakan dalam tuturannya. Kemudian Sinclair dan Coulthard R. (1995) dalam Richard (1995) yang pernah mengadakan suatu pengamatan 


\section{PUJANGGA}

terhadap peristiwa sosial (pelajaran) dalam ruang belajar, dan peristiwa sosial (pelajaran) itu disebutnya sebagai kerangka analitis yang berada paling luas dan selanjutnya secara berturutturut membagi urutan wacana hingga kebagian yang paling kecil yakni tindak. Tindak ini didefenisikan sebagai unit berbicara yang paling kecil yang bisa dikatakan mempunyai suatu fungsi. Berbagai tindak diberi nama yang disesuaikan dengan setiap fungsi wacana, seperti mencari keterangan, bertanya dan sebagainya.

\section{Konsep Tindak Tutur}

Austin (1962) menjelaskan bahwa dalam berkomunikasi, pada umumnya penutur bahasa bermaksud mengatakan sesuatu. Akan tetapi, kadang-kadang penutur bahasa tidak hanya mengemukakan sesuatu, tetapi sekaligus melakukan atau "menindakkan" sesuatu. Bandingkan dua pernyataan berikut.

(13) A. Besok hari libur.

B. Saya berjanji tidak terlambat lagi.

Tuturan A hanya mengatakan sesuatu, sedangkan tuturan B, selain mengatakan sesuatu, penutur juga melakukan atau "menindakkan" sesuatu, yaitu sekaligus dia juga "berjanji".

Menrut linguis kenamaan tersebut, tindak bahasa ada yang langsung dan ada yang tidak langsung. Bandingkan kedua bentuk berikut.

a. Tindak bahasa secara langsung.

(14) Bibi: Bu minta uang untuk membeli minyak.

Majikan: Ni, Bi uangnya.

b. Tindak bahasa secara tidak langsung.

(15) Bibi: Minyaknya habis, Bu.

Majikan: Ini uang, beli sana.

Berkaitan dengan ide tersebut, Austin (1962) membedakan tiga jenis tindakan dalam konsep tindak bahasa (speech act), yaitu tindakan lokusi, ilokusi, dan perlokusi (dalam Lyons 1979:725--730).

Tindak bahasa yang pertama, tindakan lokusi (locutionary act), adalah suatu tindakan mengatakan sesuatu atau tindakan membuat suatu tuturan, yaitu proses memproduksi tuturan yang bermakna. Dengan cara mengatakan sesuatu itulah, suatu tindakan dilakukan (cf. Lyons 1981:183--184; 1996:240), atau tindak bahasa lokusi adalah tindak bahasa yang dilakukan pembicara yang berhubungan dengan mengatakan sesuatu atau an act of saying something (cf. Syamsuddin (1992:47--48). 
Kedua, tindak bahasa ilokusi (illocutionary act) adalah tindakan yang dilakukan dalam mengatakan sesuatu membuat pernyataan (Lyons 1979:730) atau menurut Hurford dan Heasley (1994:244), tindak ilokusi yang dilakukan oleh pembicara yang sedang membuat suatu tuturan adalah tindakan yang dipandang menurut kemaknawian tuturan dalam konvensi sistem interaksi sosial. Ilokusi adalah tindakan yang ditentukan oleh konvensi sosial. Tindak bahasa ilokusi adalah tindak bahasa yang dilakukan pembicara berkaitan dengan perbuatan dalam hubungan dengan mengatakan sesuatu atau an act of doing something in saying something (cf. Syamsuddin (1992:47--48). Dalam kaitan itu,Brown dan Yule (1983:230--232) menjelaskan bahwa di dalam menuturkan suatu kalimat, si penutur tidak semata-mata menyatakan sesuatu, tetapi kadangkadang juga "menindakkan" sesuatu. Lebih tegasnya, dengan menuturkan suatu kalimat, penutur dapat dipandang telah melakukan suatu tindakan, yaitu tindakan ilokusi. Secara konvensional yang dikategorikan sebagai tindakan ilokusi, selain yang sudah disebutkan di atas "berjanji", menurut Austrin (1962), adalah (a) menyapa, (b) menuduh, (c) mengakui, (d) meminta maaf, (e) menantang, (f) mengeluh, (g) berdukacita, (g) mengucapkan selamat, (h) menolak, (i) menyesalkan, (j) mengizinkan, (k) memberi salam, (l) meminta diri, (m) menghina, (n) memberi nama, (o) menawarkan, (p) memuji, (q) memprotes, (r) berterima kasih, dan (s) bersulang (Hurford dan Heasley 1994:244; cf. Kaswanti Purwo 1984:19--20).

Dengan mengutip pendapat Austin (1962), Brown dan Yule (1983:230--232) menjelaskan tindak bahasa yang ketiga, yaitu tindakan perlokusi (perlocutionary act). Menurutnya, dengan menuturkan suatu kalimat, penutur juga melakukan tindakan perlokusi yang dapat dideskripsikan berdasarkan pengaruh tindakan ilokusi pada pendengar. Tindakan yang disebabkan oleh tindak ilokusi dapat lebih dari satu. Perlokusi adalah tindakan yang dilakukan dari sesuatu yang dikatakan dengan cara melakukan sesuatu membuat seseorang percaya bahwa sesuatu itu benar. Dengan demikian, tindak bahasa perlokusi adalah tindak bahasa yang mengakibatkan kawan bicara bertindak suatu tindakan dalam mengatakan sesuatu atau an act of some effect beccause of doing something in saying something. Hurford dan Heasley (1994:243) menyatakan bahwa perlokusi yang dilakukan oleh pembicara yang sedang membuat tuturan adalah tindakan yang menyebabkan suatu akibat tertentu pada pendengar dan yang lain.

\section{Beberapa Ilustrasi Tindak Tutur}

Berikut ini diberikan contoh tindak bahasa lokusi, ilokusi, dan perlokusi. Dari contohcontoh tersebut kita dapat mengidentifikasi hal-hal apa sajakah yang dapat "ditindakkan" di dalam kalimat tersebut.

1. Dalam suatu rapat atau pertemuan antara karyawan dan pemimpin suatu instansi, seorang peserta rapat, Pak Gufron, mengangkat tangan kirinya dan mengatakan,

(16) "Sekarang sudah pukul 17.30. "Secara spontan pemimpin rapat mengangguk dan meyatakan bahwa pertemuan ditutup.

Lokusi : "Sekarang sudah pukul 17.30."

Ilokusi : Pak Gufron melakukan tindakan "mengingatkan" semua peserta rapat tentang waktu ketika itu yang sudah hampir Magrib, atau waktu salat Asar hampir habis.

Perlokusi: Pemimpin instansi tersebut melakukan tindakan "mengangguk" sebagai isyarat bahwa beliau menyetujui rapat ditutup, yang kemudian melakukan tindakan "menutup" rapat sore itu untuk memberi kesempatan kepada sebagian peserta rapat melaksanakan salat Asar. Jadi, kalimat Pak Guffron Sekarang sudah pukul 17.30 tidak hanya mengatakan sesuatu, tetapi juga meminta, memohon, atau menyuruh pemimpin rapat nmenutup rapat tersebut. Perlokusi (akibat tindak ilokusi tersebut) ada dua, yaitu pemimpin rapat (a) "mengangguk" dan (b) menutup rapat. Kalimat tersebut gramatikal, bermakna, dan berterima.

2. Majikan memanggil pembantunya sambil memperlihatkan kerah baju suaminya yang sedang dijemur dan menyatakan, (17) "Bi kerah baju ini masih hitam." Kemudian, si Bibi mengambil baju tersebut sambil meminta maaf dan dan segera pergi ke sumur.

Lokusi : "Bi kerah baju ini masih hitam." 
Ilokusi : Majikan melakukan tindakan "memperingatkan" pembantunya bahwa mencuci pakaian tidak asal-asalan; mencuci pakaian harus bersih.

Perlokusi: Pembantu melakukan tindakan "meminta maaf" dan "mencuci ulang" baju tersebut.

Perlokusi (akibat ilokusi) tersebut ada dua, yaitu si Bibi mengucapkan (a) "permintaan maaf" dan (b) "mencuci ulang baju".

Dapat pula dikatakan bahwa kalimat yang dikatakan majikan Bi kerah baju ini masih

hitam tidak semata-mata memberi tahu kepada pembantunya bahwa kerah baju masih kotor, tetapi sebetulnya majikan "menindakkan" atau memerintahkan dan menyuruh pembantunya mencuci kembali baju yang ternyata belum bersih. Kalimat tersebut juga gramatikal, bermakna, dan berterima.

3. Suatu malam Rin, anak seorang ibu, dikunjungi pacarnya. Karena merasa malam sudah larut, si ibu berkata kepada anak gadisnya, (18) "Rin, obat nyamuk di dapur, ini sudah jam sembilan."

Lokusi : " Rin, obat nyamuk di dapur, ini sudah jam sembilan."

Ilokusi : Si ibu memerintahkan anak gadisnya, Rin, supaya segera menyemprot kamarnya dan kamar adiknya karena waktu sudah pukul 09.00 malam. (Pekerjaan itu merupakan tanggung jawabnya setiap malam.)

Perlokusi: (a) Tidak lama setelah itu, si pemuda melakukan tindakan "pamit" kepada kekasihnya, Rin.

(b) Rin melakukan tindakan "menyemprot" kamarnya dan kamar adiknya dengan obat nyamuk.

Akibat ilokusi tersebut (perlokusinya) ada dua, yaitu (a) si pemuda pamit dan (b) Rin menyemprot kamar. Sang Ibu dengan mengatakan ini sudah jam sembilan tidak semata-mata memberi tahu keadaan jam pada waktu itu; Sang Ibu juga "menindakkan" sesuatu, yaitu menyuruh Rin menyemprotkan obat nyamuk ke kamar adiknya, dan "menyuruh" pacar Rin supaya segera pulang. Kalimat itu pun gramatikal, bermakna, dan berterima.

4. Dalam suatu penerbangan, pramugari menghampiri seorang penumpang dan mengatakan, (19) "Ini coca cola dan ini kopi."

Lokusi : " Ini coca cola dan ini kopi."

Ilokusi : Tuturan tersebut tidak semata-mata memberitahukan ini coca cola dan ini kopi, tetapi juga menawarkan minuman kepada penumpang tersebut, apakah mau minum coca cola ataukah mau minum kopi.

Perlokusi: Penumpang bereaksi, "Coca cola, Mbak, terima kasih."

Akibat ilokusi tersebut (perlokusinya) adalah si penumpang melakukan tindakan (a) meraih gelas coca cola dengan tangannya dan (b) mengucapkan terima kasih.

Kalimat pramugari Ini coca cola dan ini kopi tidak sekadar menyatakan ada dua jenis minuman, coca cola dan kopi, tetapi juga menawarkan minuman kepada penumpangnya, apakah mau minum coca cola ataukan minum kopi. Kalimat pramugari tadi gramatikal, bermakna, dan berterima.

Menurut Hymes (1992) dalam Arifin dkk. (2016), unsur bahasa dalam etnografi komunikasi ada delapan macam, sebagai berikut.

\section{Konteks Latar (S, setting)}

Konteks latar (setting) bersifat fisik dan meliputi tempat (ruang) dan waktu atau tempo terjadinya tuturan. Latar suasana merupakan latar yang mengacu pada suasana psikologis yang menyertai tuturan. Perhatikan percakapan antara seorang ibu dan anaknya yang masih kecil, yang malas bangun tidur.

Ibu : (20) Bangun, sayang. Udah ada matahari, tuh. Ayo, bangun, nanti Adek kesiangan.

Adek: (21) Nanti, Mah, lima menit lagi. Adek ngantuk banget. Contoh lain seperti berikut. 
(21) a. [A dan teman sekelasnya mendiskusikan wacana transaksional, dibimbing dosen]:

A: Kalau begitu, apa yang dimaksud dengan wacana transaksional, Pak?

b. [A dan temannya berdiskusi bebas tentang wacana transaksional]:

A: Kalau gitu, wacana transaksional itu, apa dong?

Diskusi (21a) menggunakan bahasa formal karena di bawah bimbingan dosen, tetapi contoh (21b) menggunakan bahasa tidak formal karena suasananya santai, berdiskusi bebas bersama temannya.

\section{Konteks Peserta (P, partisipant)}

Partisipan dalam berkomunikasi langsung ataupun tidak langsung terdiri atas pembicara atau penulis (penyapa) dan pendengar atau pembaca (pesapa). Yang berkaitan dengan partisipan ialah status sosial, usia, latar belakang pendidikan, pengalaman, serta hubungan di antara mereka, baik secara hubungan pribadi maupun dinas. Berdasarkan pengalaman bergaul dengan para anggota masyarakat, kita dapat memahami ujaran berikut.

(22) [Ketika dua orang mengobrol di dekat ruang ujian,

A memperingatkan]:

A: Maaf, Dik, di sini masih ada ujian.

Tuturan (22a) disampaikan oleh A bukan hanya pemberitahuan, melainkan juga untuk memperingatkan orang yang sedang mengobrol di dekat ruang ujian agar berhenti mengobrol, mengobrollah lambat-lambat, atau mengobrollah ke tempat lain.

Partisipan mengacu pada peserta tuturan, yakni siapa pun yang terlibat dalam tuturan, langsung atau tidak langsung, yaitu pembicara (orang pertama) dan yang diajak berbicara (orang kedua). Orang ketiga tidak menjadi peserta tuturan; ia menjadi orang yang dibicarakan.

\section{Konteks Hasil (E, ends)}

Hasil berupa tanggapan atas suatu pertuturan. Hasil itulah yang diharapkan penutur dan menjadi tujuan akhir percakapan. Misalnya, seorang dosen memberikan kuliah "Fungsi awalan meng- dalam bahasa Indonesia" kepada mahasiswa S-1 Jurusan Bahasa Indonesia semester akhir. Kuliah itu bisa mencapai tujuan, tetapi bisa juga tidak karena hal itu amat bergantung pada penyampaian pengajar dan penerimaan atau tanggapan mahasiswa (peserta percakapan) ketika menerima kuliah itu. Tidak semua bahan dan tujuan yang baik dapat berhasil baik.

\section{Konteks Pesan atau Amanat $(A$, act $)$}

Pesan (amanat) mengacu pada bentuk dan isi tuturan. Dalam kajian pragmatik, bentuk pesan meliputi lokusi, ilokusi, dan perlokusi. Bentuk amanat, misalnya esai, cerita, pengumuman, iklan, undangan, surat, dan pengumuman. Perhatikan perbedaan antara bentuk dan isi amanat berikut.

(23) a. Perhatian, perhatian! Para penumpang tujuan Bandar Lampung harap segera naik ke pesawat melalui pintu satu.

b. Petugas meminta agar para penumpang tujuan ke Bandar Lampung segera naik ke pesawat melalui pintu satu.

Amanat pada contoh (23a) berbentuk pengumuman, yang isi informasinya 'mengharapkan agar para penum-pang tujuan Bandar Lampung segera naik ke pesawat melalui pintu satu', sedangkan amanat pada contoh (23b) berupa permintaan, yang'meminta agar para penumpangtujuan Bandar Lampung segera naik ke pesawat melalui pintu satu'. Kedua pesan itu berbeda efeknya walaupun isi informasinya sama. 


\section{Konteks Cara $(K$, key $)$}

Konteks cara mengacu pada cara, nada, sikap, atau semangat ketika melakukan percakapan, misalnya percakapan dengan bersemangat menyala-nyala, dengansedih, dengan riang, dengan santai, akrab, atau dengan sangat meyakinkan pihak lain. Kemudian, apakah informasi disampaikan dengan lisan, tertulis, surat, radio, dsb. Pembicaraan akan berbeda jika disampaikan dengan nada serius, humoris, sinis, sarkastis, dan rayuan.

\section{Konteks Sarana (I, instrument)}

Sarana atau media mengacu pada apakah seseorang berbahasa lisan atau tertulis dan mengacu pada variasi bahasa. Berdasarkan pemakaiannya, akan didapatkan, misalnya percakapanragamtulis resmi dan percakapanragamtulis tidak resmi.

\section{Konteks Norma (N, norms)}

Norma mengacu pada aturan yang membatasi tuturan. Misalnya, apa saja yang boleh dibicarakan, apa saja yang tidak boleh dibicarakan pada suatu kesempatan, bagaimana cara membicarakannya (dengan halus, kasar, baik, terbuka, tertutup, bersungguh-sungguh, atau bergurau).

Dalam pertemuan ceramah, misalnya, pendengar cenderung diam, hanya mendengarkan atau tidak mendengarkan ceramah, ada-tidak ada tanya jawab. Keadaan itu berbeda dari pertemuan diskusi, peserta diskusi aktif menyampaikan tanggapan, komentar, kritik, ataupun argumentasinya.

\section{Konteks Jenis (G, genre)}

Yang dimaksud dengan konteks jenis ialah jenis atau bentuk wacana, yang langsung menunjuk pada kategori wacana yang disampaikan. Misalnya, sebuah wacana termasuk kategori pantun, cerita, teka-teki, novel, karya ilmiah, bahan kuliah, pidato, doa, atau dialog. Perhatikan contoh berikut.

(24) empat kali empat

enam belas

sempat tidak sempat

harap (surat ini) dibalas

Wacana di atas merupakan kategori pantun karena wacana itu terdiri atas 4 baris, bersajak a b a b, 2 baris pertama disebut sampiran, dan 2 baris terakhir disebut isi. Sebuah pesan akan berbeda ketika diterima pendengar jika pesan itu disampaikan dalam genre puisi, prosa. umpatan, doa, lelucon, ungkapan, ataupun iklan.

Kajian Austin (1962) dalam Muhadjir (2015:235) memerinci tindak tutur menjadi beberapa kelompok. Di antaranya adalah sebagai berikut.

a. Representative (representatif): tindak tutur yang memeriksa suatu keadaan atau peristiwa, seperti pernyataan, dugaan, laporan, atau pemerian. Tindak tutur ini dapat saja benar atau salah. Misalnya: (25) Ini namanya lumpia (padahal mestinya risoles).

b. Commissive (komisif): tindak tutur yang mengikat penuturnya untuk melakukan sesuatu, seperti janji, sumpah, atau ancaman. Misalnya: (26) Siapa saja yang ketahuan mencontek, langsung saya kasih $E$.

c. Directive (direktif): tindak tutur yang dimaksudkan agar pendengarnya melakukan suatu tindakan, seperti minta tolong, perintah, menantang, mengundang. Misalnya: (27) Harap Tenang.

d. Declaration (deklarasi): tindak tutur yang dapat mendatangkan atau mengubah suatu keadaan, seperti pembabtisan, pengukuhan, keputusan. .Misalnya: (28) Saudara kami nyatakan lulus menjadi doktor. 
e. Expressive (ekspresif): tindak tutur yang menunjukkan keadaan psikologis atau sikap penuturnya, seperti memberi salam, minta atau memberi maaf, ucapan selamat, ucapan bela sungkawa, atau memberi pujian. Misalnya: (29) Maaf, Pak, saya terlambat.

\section{SIMPULAN}

Beberapa tuturan dalam pembicaraan dengan menggunakan bahasa Indonesia, yang diteropong berdasarkan etnografi komunikasi sangatlah kompleks. Dalam bahasa Indonesia terdapat ribuan kata kerja yang dapat digunakan untuk berbagai tuturan.

Tuturan menurut Austin terbagi menjadi lima macam, yaitu

a. verdiktif, seperti melakukan, estimasi, menyatakan, dan memberikan;

b. eksersitif, seperti memerintah, menunjuk, dan memberi nasihat;

c. komisif, seperti melakukan promosi, menyatakan makud, dan bertaruh;

d. behabitik, seperti meminta maaf, memberi ucapan selamat, dan terima kasih;

e. ekspositif, seperti membantah, mendesak, dan memastikan.

Searle juga membagi tuturan menjadi lima macam, yaitu

a. asertif, misalnya menyatakan, mengusulkan membual, mengeluh, mengemukakan pendapat, dan melaporkan.

b. direktif; misalnya memesan, memerintah, memohon, dan menunut.

c. komisif, seperti menjanjikan, menawarkan, dan berkaul.

d. ekspresif, misalnya mengucapkan terima kasih, mengucapkan selamat, memberi maaf, memuji, atau mengucapkan belasungkawa.

e. deklaratif, misalnya mengudurkan diri, membabtis, memecat, memberi nama, dan menjatuhkan hukuman.

Terdapat delapan unsur situasi bahasa, yang dapat memengaruhi suatu

komunikasi, yaitu 1) latar waktu, tempat, dan suasana, 2) partisipan, komunikator dan komunikan, 3) hasil, 4) amanat, 5) cara, 6) instrumen, 7) norma, dan 8) genre.

Latar (setting) yang melatarbelakangi suatu tuturan dapat bersifat fisik, yang meliputi tempat (ruang) dan waktu atau tempo terjadinya tuturan, sedangkan. latar suasana merupakan latar yang mengacu pada suasana psikologis yang menyertai tuturan. 


\section{PUSTAKA ACUAN}

Alwi, Hasan. 1992. Modalitas dalam Bahasa Indonesia. Yogyakarta: Kanisius.

Arifin, E. Zaenal/ 2015. "Lokusi, Ilokusi. dan Perlokusi”. Dalam Pujangga, Volume II, No. 1. Tahun 2016. Jakarta: Universitas Nasional.

Austin, J.L. 1972. How to do Thing With Words. Harvard University Press: Cambridge, Mass.

Bright, William. 1992. International Encyclopedia of Linguistics. Oxford: Oxford University Press.

Brinton, Lurel J. 1990. The Development of English Aspectual Systems. Cambridge: Cambridge University.

Chambers, J.K. and Peter Trudgill. Dialectology. Cambridge:University of Toronto and Université de Lausanne.

Carlson, Lauri. 1981. "Aspect and Quantification". Dalam Philip J. Tedeschi. Syntax and Semantics Vol. 14, hlm. 31--64. New York: Academic Press.

Chaer, Abdul dan Leonie Agustina. 1995. Sosiolinguistik Perkenalan Awal. Jakarta: PT Rineka Cipta.

Djajasudarma, 1994. Pragmatik Indonesia. Jakarta: PT Rineka Cipta.

Hymes, D. 1972. Models of The Interaction of Language and Social Life. In J. Gumperz \& D. Hymes (Eds.), Directions in Sociolinguistics: The Ethnography of Communication. New York: Holt, Rinehart, Winston.

Hymes, Dell. 1972. Language in Culture and Society. New York: Harper and Row.

http://didin.lecture.ub.ac.id/sosiolinguistik/bahasa-dan-usia/(Diunduh $\underline{25 / 02 / 2018)}$

http://staff.unand.ac.id/ikerevita/2017/04/10/antara-tuturan-kalimat-danpelintiran/(Diunduh 9 Mei 2018)

https://zainurrahmans.wordpress.com/tag/perbedaan-kalimat-dan-tuturan/(Diunduh 9 Mei 2018)

https://www.brainly. co.id»/ (Diunduh 17/06/2018)..

http://www. repositori.perpustakaan. kemdikbud. go.id/id/eprint/4780/(Diunduh 18/06/2018). 
https://www.cambridge.org/.../dialectology/3B5DB46311E1.(Diunuh 18/06/2-18).

Junaiyah, H.M. dan Zaenal Arifin. 2016. Wacana Transaksional dan Interaksional. Tangerang: Pustaka Mandiri.

Kaswanti Purwo, Bambang. 1990. "Pragmatik dan Linguistik”. Dalam "Penataran Linguistik Angkatan I". Jakarta: Pusat Bahasa.

Lapasau, Merry dan Arifin, E. Zaenal. 2016. Sosiolinguistik. Tangerang: PT Pustaka Mandiri.

Leech, Geoffrey. 1983. Principles of Pragmatics. Terjemahan ke dalam Bahasa Indonesia dilakukan oleh M.D.D Oka. 1993. Prinsip-Prinsip Pragmatik. Jakarta: UI Press:

Levinson. 1983. Pragmatics.Cambridge: CU Press.

Muhadjir. 2015. Semantik dan Pragmatik. Tangerang: Pustaka Mandiri.

Rosmanuddin, Sapriandi A. "Berapa Jumlah Bahasa Daerah di Indonesia?

Rosmanuddin, Saparudin A. 2017/http//:www.portalsatu.com/read/ budaya/ 36621/(Diunduh 17/06/2018).

Rustono. 1999. Pokok-Pokok Pragmatik. Semarang: IKIP Semarang Press.

Saville, Muriel. Troike. 2003. The Ethnography of Communication: An Introduction.Third Edition. Blackwell Publishing.

Sumarsono dan Paina Partana. 2004. Sosiolinguistik. Yogyakarta: SABDA.

www. usahid.ac.id/wp-content/ uploads/etnografi-komuni-kasi/(Diunduh 25/02/2018). 